\title{
Geological Mapping and Assessment for Measurement the Electric Grid Transmission Lines in West Sumatera Area, Indonesia
}

\author{
Husnul Kausarian", Batara", Dewandra Bagus Eka Putra ${ }^{\#}$, Adi Suryadi", Muhammad Zainuddin Lubis*

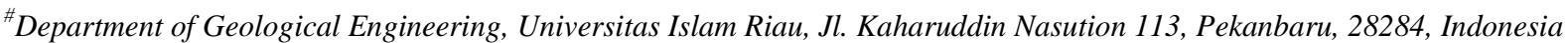 \\ E-mail: husnulkausarian@eng.uir.ac.id,batarabtr@gmail.com,dewandra.bagus@eng.uir.ac.id, adisuryadi@eng.uir.ac.id \\ *Geomatics Engineering, Politeknik Negeri Batam, Batam 29461, Indonesia \\ E-mail: zainuddinlubis@polibatam.ac.id
}

\begin{abstract}
Energy needs in Indonesia increase rapidly, and Indonesian Government pays serious attention to this program. One of this program application is to build the new power plant and its transmission line in Alam Pauh Duo, District of Solok Selatan. The geological condition in this area consists of Geomorphology Units of the Hills and High Geomorphological Units with the altitude of about $900-500 \mathrm{~m}$ (meters) with lithology of volcanic rock and intrusion of granite and granodiorite. The review survey (checking and renaissance) was applied for geological mapping in this study by a road sweeping or tracking using a handheld GPS. The result of this mapping and assessment are the coordinate values of the markers or dividing marks that are already available and scattered in each location point. The final result is a map that has a description of the location of Land Power Plant and Transmission Tower. There are 15 transmission towers planned for the builders as well as the power plant (GI). The required land area of each transmission tower is about $15 \times 15 \mathrm{~m}$ (meters) up to $20 \times 20 \mathrm{~m}$ and the land area for 3ha (hectare) power plant (GI) development. Then the distance between each tower transmission approximately 200 meters.
\end{abstract}

Keywords - power plant; transmission line; Alam Pauh Duo; geological mapping; geological assessment

\section{INTRODUCTION}

The rapid growth for electric energy consumption in Indonesia increase continuously in line with the growth rate of the industry, and the number of residents and the Indonesian government is currently keen to realize this infrastructure, one of which is to build electricity transmission network. One source of this electrical energy is geothermal. Regency of Solok Selatan is one of the areas in Indonesia that have the potential of natural resources that is geothermal energy because Solok Selatan region has a geological condition that supports the formation of hot springs, indirect utilization developed for geothermal power generation [1]. Therefore, with the existence of geothermal sources that can generate electricity is potential to be built electric transmission lines that are around this area [2].

Geothermal energy is a relatively environment-friendly energy source because it comes from the inner heat of the earth. Water that is pumped into the earth by humans or natural causes (rain) is collected to the surface of the earth in the form of steam, which can be used to drive turbines to produce electricity. The cost of exploration, as well as the capital cost of geothermal power plants, is higher than other power plants that use fossil fuels. However, once it starts operating, its production costs are low compared to fossil fuel power plants. Power Transmission Is a process of distributing electricity [3]-[5] from the power plant to power distribution lines (power plant distribution) so that it can be distributed up to consumer electric users [6].

\section{MATERIAL AND METHOD}

The Study site is located in Alam Pauh Duo, Alam Pauh Duo Sub-district, District of Solok Selatan, Geographically

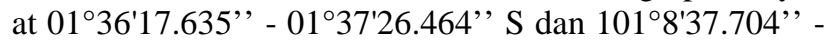
$101^{\circ} 744.508^{\prime \prime}$ N. Landform at the study site is an area of hills, and there are also local community plantations (Fig. 1).

Geothermal In the area of Solok Selatan, or more precisely in the Muara Laboh, had a lot of hot springs associated at the Valley of Suliti River. The tectonic basin along the $30 \mathrm{~km}$ and a width of 2-3 km at an altitude of 450 meters above the sea level. The tectonic basin in the North of Muara Labuh. From the start of the southern end of the basin, topography continues to climb, and the hot springs discovered at a distance of more than $3 \mathrm{~km}$ from the Mount Sikapa (656m) to the Mount Sapan Malulong (850m). Areas to the south are called Sikapa Hill located at the South of Muara Labuh. 


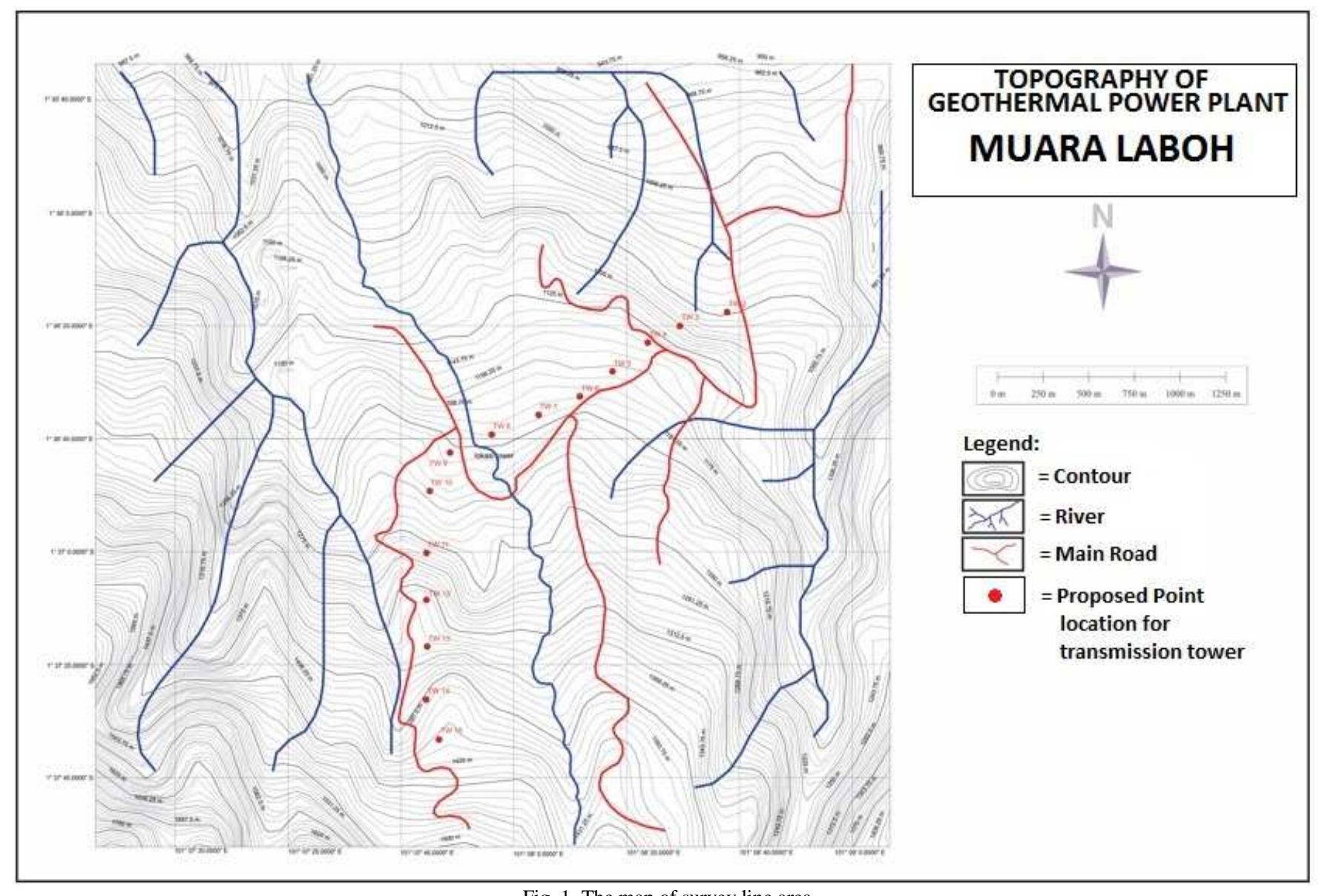

Fig. 1 The map of survey line area

The survey area has a landscape classified as Geomorphology Hills unit and Geomorphology High Hills Unit with a height of about 900-500m (meters). Lithology contained in the research area is volcanic rock and intrusion of granite and granodiorite. Potential energy in this area is geothermal energy because that area has many of hot springs.

In general, the survey area included in stratigraphic from young to old is composed of Paleozoic metamorphic rocks (bedrock) with the age of Perm to Carbon which composed by metamorphic rocks, metasediment and Pre-Tertiary volcanic rocks with the age of Mesozoikum, metasedimentrocks with the age of Triassic-Jurassic. Members of slate and shale from Tuhur Formation, Member of limestone from Kuantan Formation and sedimentary and volcanic rocks from Sigunyur Formation. Tertiary rocks consisting of a group of sedimentary rocks and volcanic rocks group. Group volcanic rocks are divided into two age groups, namely groups of Eocene volcanic rocks from Bandan Formation and Oligo-Miocene volcanic rocks from Painan Formation. Pre-Mesozoic rocks in the Mesozoic-break through the granite-diorite with the age of Jura-Cretaceous. Tertiary rocks intruded by granodiorite and diabase rocks with the age of Miocene. Quaternary volcanic precipitate mainly covered the top rock of the groups. Surface sediment consists of alluvium, lacustrine and swamp sediment (recent age).

Structures that affect this area is the Sumatra Fault, which is dextral strike-slip fault and the normal fault with the direction of northwest east west. Fault growing in this area is a normal fault and strike-slip fault. Normal fault generally has the direction of northwest southeast, which is a part of the Semangko Fault. While fault that has direction east west allegedly closely associated with diabase intrusive rocks. Faults developed in the rock group of Painan Oligo-Miocene Formation. Fault limited to the lithological contact between intrusive rocks diabase $(\mathrm{Tdb})$ and integral volcanic rocks (Qou). Strike-slip Fault relatively has North-south direction cut in several places on normal faults. In some locations, this fault is estimated as controlling the course of the hydrothermal solution and lithological contacts (Fig. 2).

The survey (reconnaissance) used in Alam Pauh Duo, Alam Pauh Duo sub-district, District of Solok Selatan is sweeping the street or track using GPS handheld [7]-[11]. The goal in reviewing survey (reconnaissance) is looking for a peg or re-check the presence of the power plant and the transmission tower [12], [13] that based on the report from the initial survey. The methods also to investigate the geological conditions in the field including the lithological characteristics and access path between each power plant and the tower destination point [14], [15].

The method was used in software (global mapper) is to analyze contours using srtm map as a base map, the result of the analysis is a map of elevation or topographic of the area. Other data used in addition to field observations are topographic data of SRTM (Sumatera srtm 57_12) and Landsat 7 for generating the whole transmission lines in one map. For the complete flowchart of the methodology that was used, can be seen on Fig. 3. 


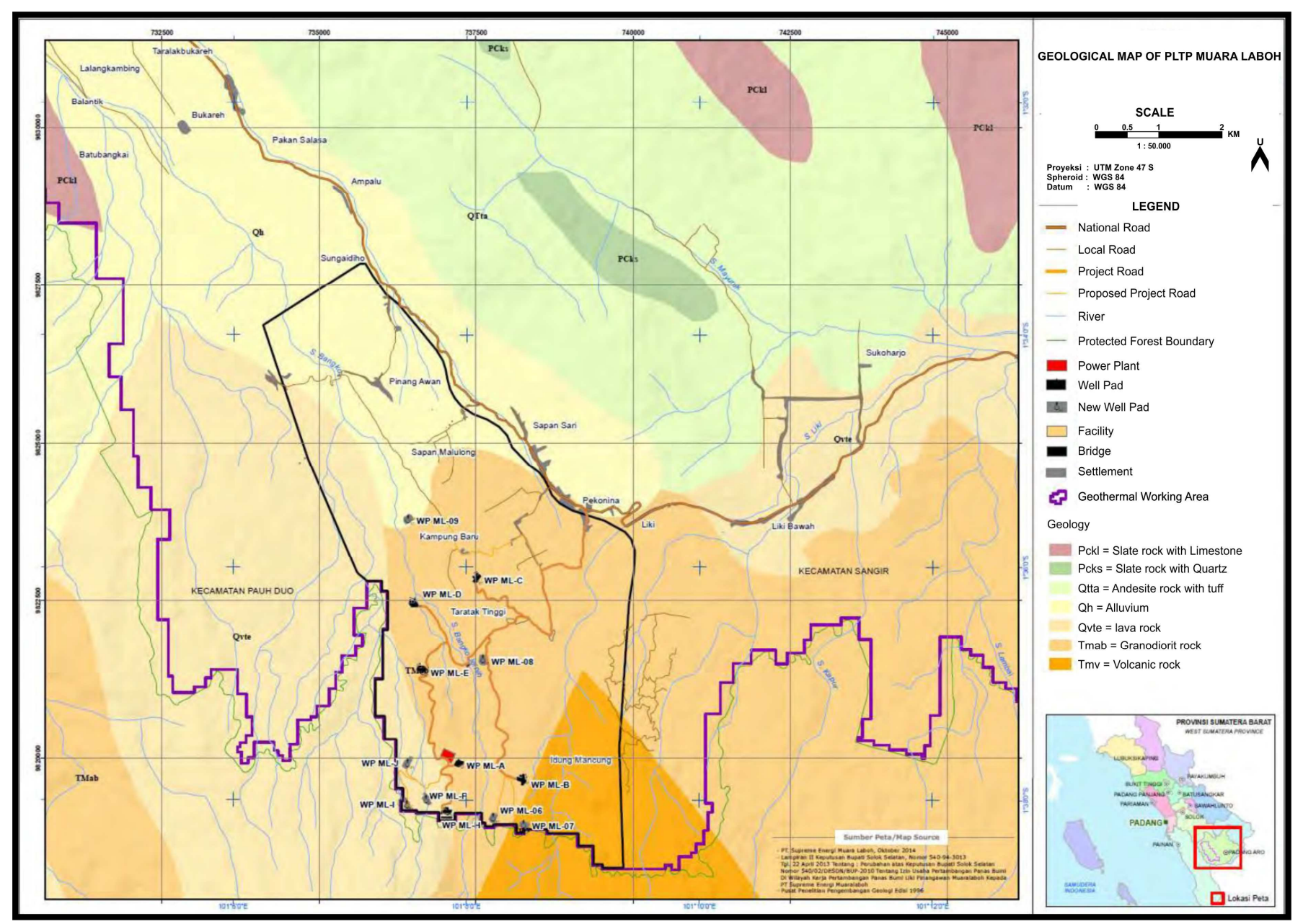

Fig. 2 Geology regional map of survey area

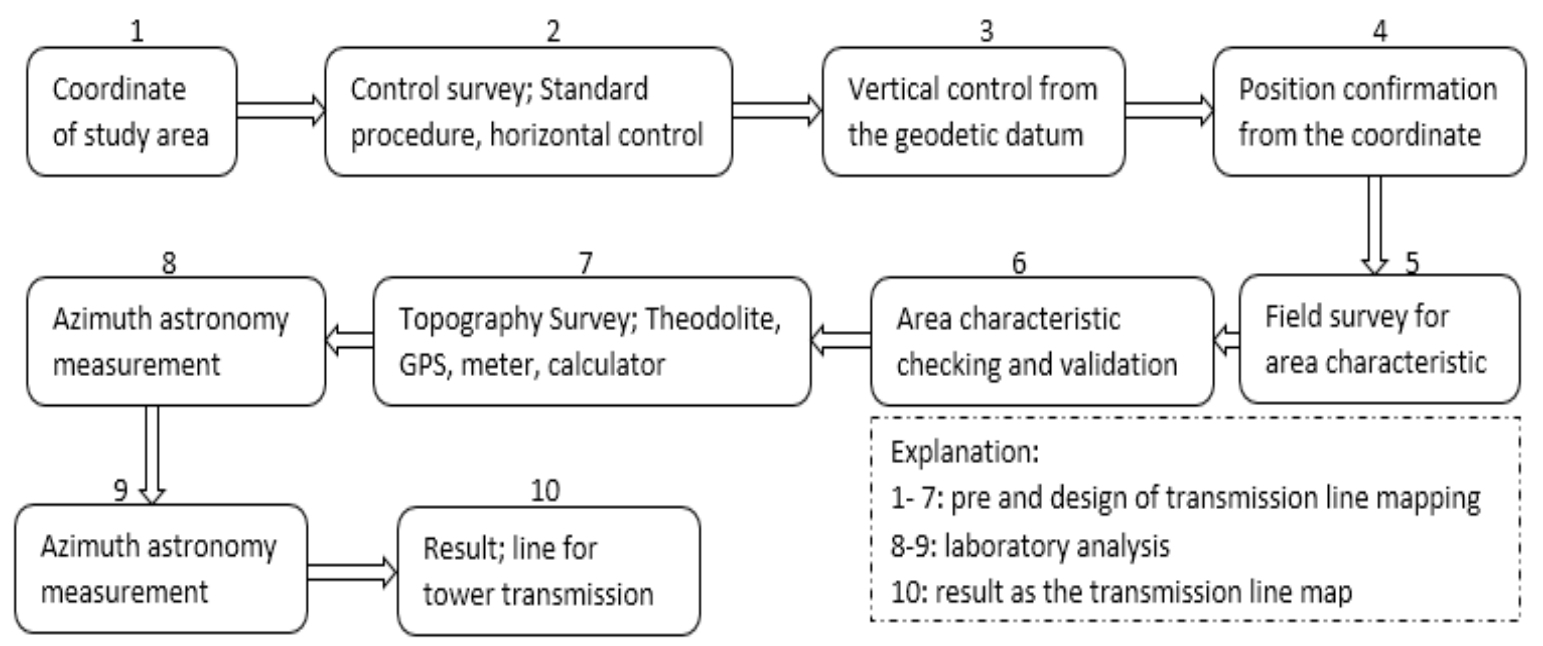

Fig. 3 Flowchart of the methodology in this study

The transmission can be airway and underground conduits, but generally in the form of the airway. Electrical energy is channeled through aerial transmission line [16].

Generally, use bare wire that relies on air as the insulating medium between the wires. Moreover, to refute/stretching wires with the height and distance are safe for humans and the surrounding environment. The conductor wires mounted on sturdy building construction commonly called the tower. Inter/electric tower and wires insulated by an insulator.

\section{RESULTS AND DISCUSSION}

The form of the survey data taken in the form of the coordinate value of stakes or pins barrier already available and distributed at each site listed in Fig. One is indicated by red dots. The existence of a limiting peg or mark to be close to the peak location of injection wells drilling geothermal power plant in Muara Laboh, up toward to the power plant (GI) under adjacent to the Main Office of the company named as PT. Supreme Energy (Fig. 4). 


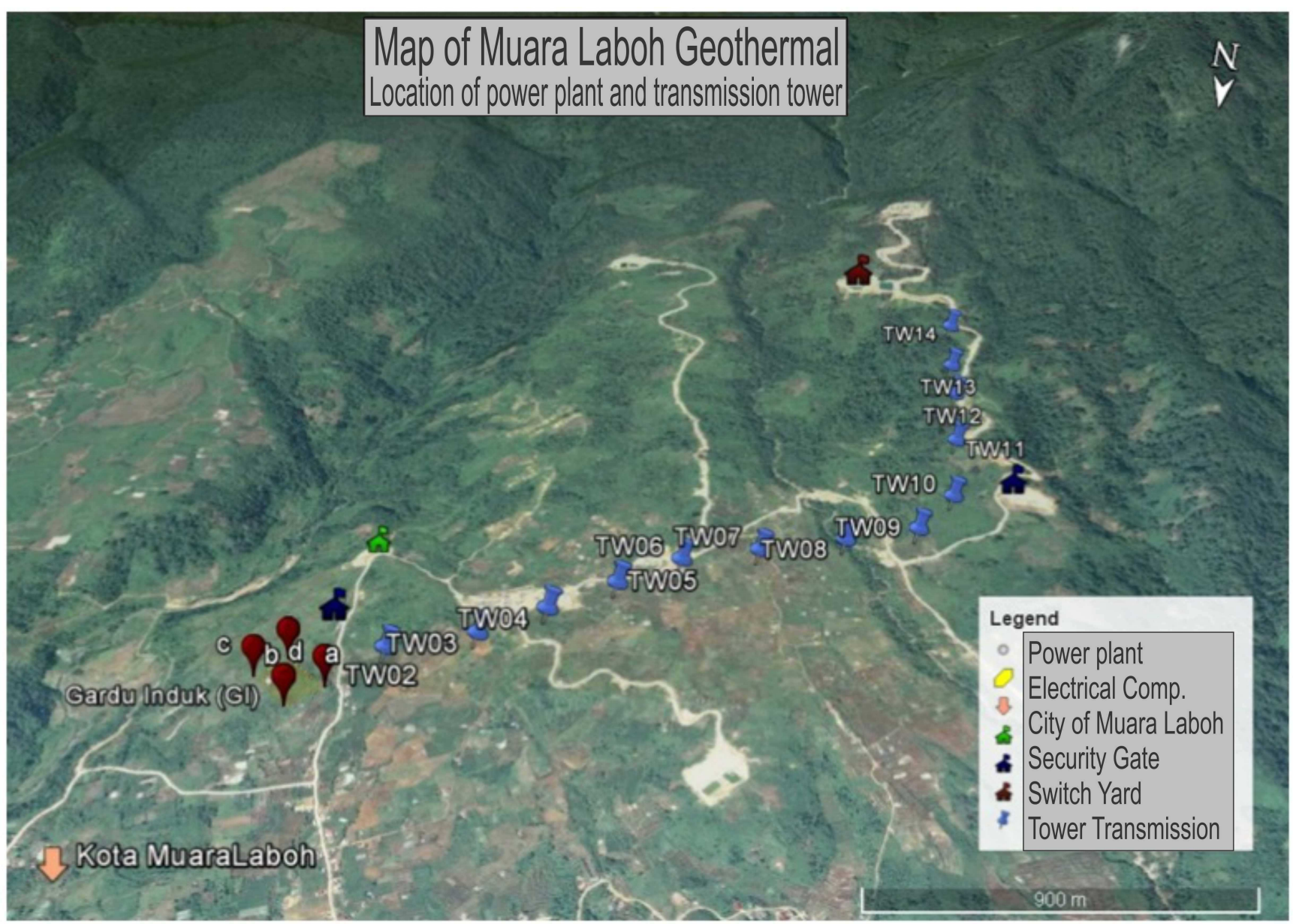

Fig. 4 Locations of the power plant and the transmission tower

Based on survey data that has been obtained then produced a map that has a description field site power plant and transmission tower. There are 15 planned develop transmission tower and power plant (GI). The land area required for each transmission tower around $15 \times 15$ meters up to $20 \times 20$ meters and the area of the land for the construction of the power plant (GI) is 3 hectares. From this calculation, the distance between each transmission towers approximately 230 meters.

Electrical energy is streaming through the aerial transmission lines rely on air as the insulating medium between the wire conductors with the surrounding objects. To refute / span wires with the height and distance are safe for humans and the surrounding environment, the conductor wires mounted on sturdy building construction, commonly called the transmission tower. There are 15 points potential locations to build a transmission tower (Fig. 4), marking the point of this site in the form of stakes barrier. Fig. 4 shows the locations around the pegs of the transmission tower (Fig. 5).

The results of field observations, field conditions are growing areas of residents, the stakes are also several locations in the valley or the outskirts of the hill (see Fig. 4). Trails road is the only central access. For the location of transmission towers, peg 1 and 15 will be determined once the location of the power plant and Switchyard has been determined. Some points of the tower mounting location as a representation of the overall location shows this region in accordance become transmission lines.

There are 10-point locations, which are transmission tower no. $2,3,4,5,6,7,8,9,10,11$, are in the villager's rice field and access roads that are usually passed by the farmers. Access from the main road leading to the transmission tower no. 2 is about 100 meters. Access from the peg of transmission tower no. 2 to no. 3 is about 200 meters. Access from the peg of transmission tower no. 3 to no. 4 is about 220 meters. Access from the peg of transmission tower no. 4 to no. 5 is about 210 meters. Access from the peg of transmission tower no. 5 to no. 6 is about 210 meters. Access from the peg of transmission tower no. 6 to no. 7 is approximately 180 meters. Access from the peg of transmission tower no. 7 to no. 8 is approximately 200 meters. Access from the peg of transmission tower no. 8 to no. 9 is approximately 200 meters. Access from the peg of transmission tower no. 9 to no. 10 is approximately 200 meters. Access from the peg of transmission tower no. 10 to no. 11 is approximately 230 meters. 


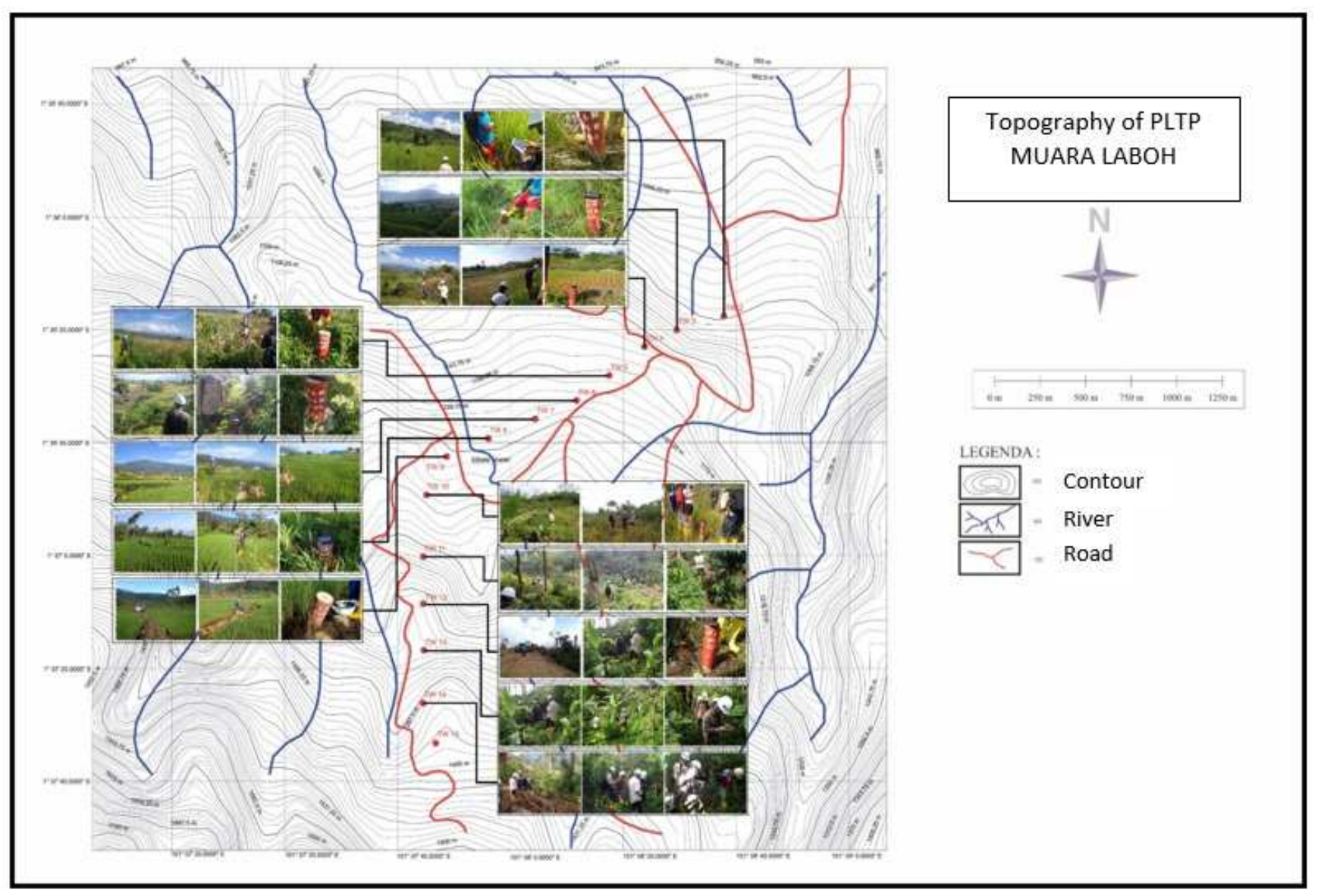

Fig. 5 The distribution map of field conditions in every transmission tower

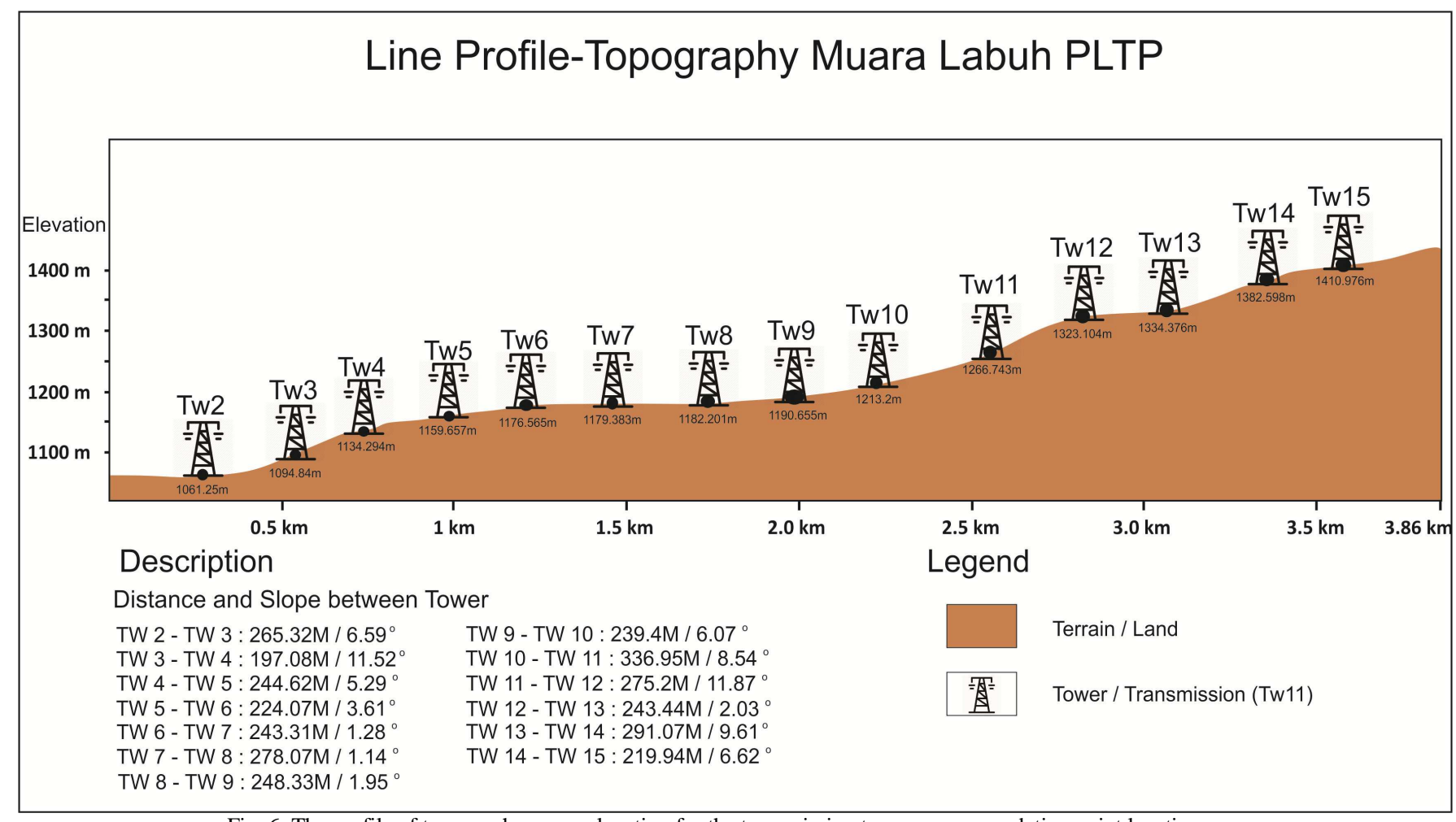

Fig. 6 The profile of topography survey location for the transmission tower recommendation point location 


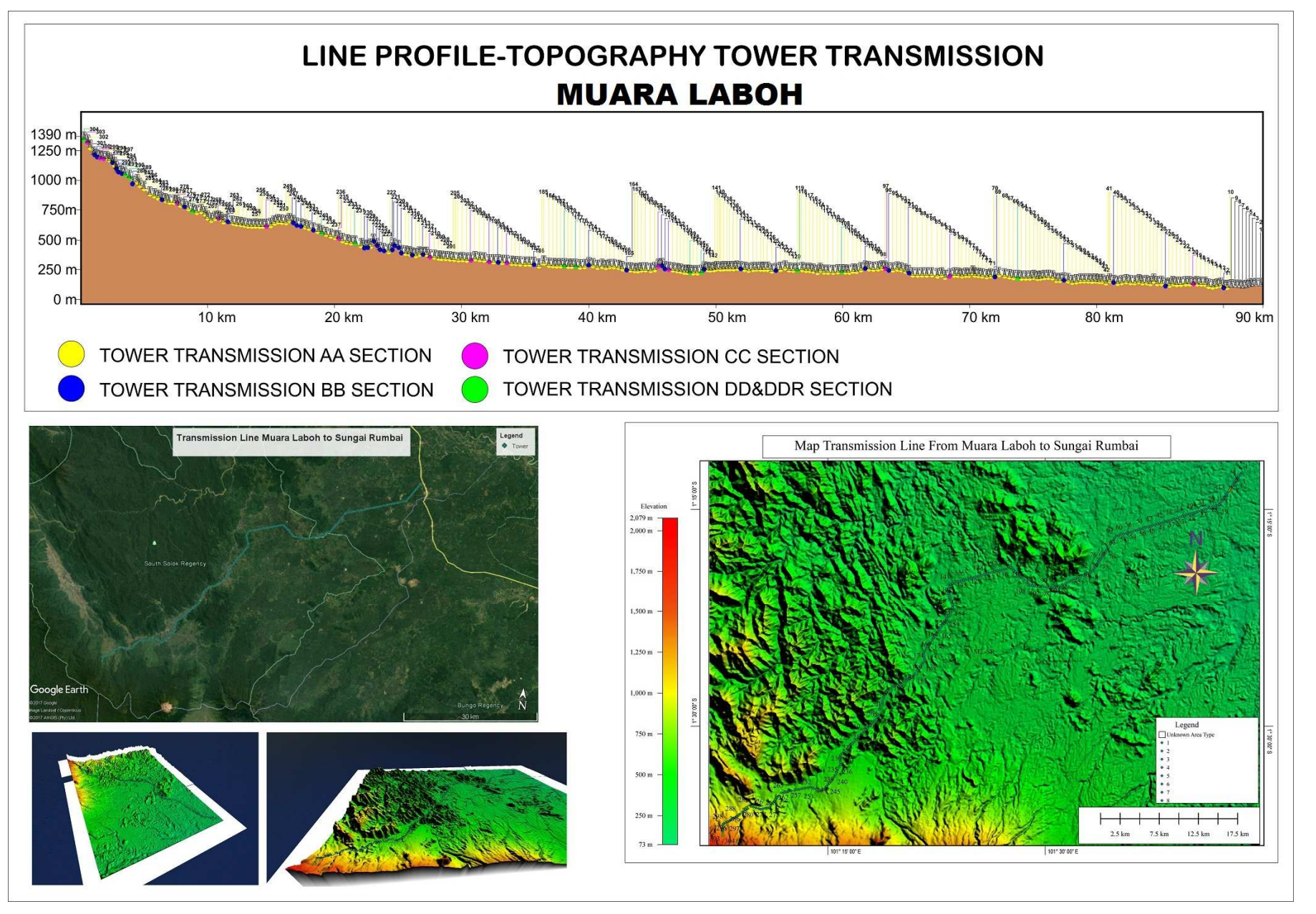

Fig. 7. The final result for the whole geological mapping and assessment for the Survey Location of the potential area for transmission tower recommendation point location. (Anti-clockwise: the total number of the transmission line based on the section, left below: the research area and it is topography by $3 \mathrm{D}$ looks, right below: the topography and altitude profile for the whole survey area

TABLE I

There are 4-point locations of the peg of transmission tower, which are located in the community garden, and there are shrubs and the road access and located alongside the hill. Those are the peg of transmission tower no. 11, 12, 13, and 14. Access from the peg of transmission tower no. 10 to no. 11 is about 200 meters. Access from the peg of transmission tower no. 11 to no. 12 is approximately 200 meters. Access from the peg of transmission tower no. 12 to no. 13 is approximately 200 meters. Access from the peg transmission tower no. 13 to no. 14 is approximately 200 meters. For the whole condition for each transmission, tower location from the real situation based on the field survey and measurement can be seen in Table 1. In general, it can be described as the appropriate location to build power transmission lines using the tower as in Fig. 6. The entire situation for the final result of geological mapping and assessment for the Alam Pauh Duo location as the potential area for building the transmission tower can be seen in Fig. 7.

THE CONDITION OF POINT LOCATION FOR TRANSMISSION TOWER IN GeOTHERMal POWER Plant, Muara Laboh.

\begin{tabular}{|c|c|c|}
\hline Tower no. & $\begin{array}{l}\text { Distance (in } \\
\text { Meters) }\end{array}$ & Situation \\
\hline 1 & 0 & Open area / Power plant \\
\hline 2 & 100 & \multirow{10}{*}{$\begin{array}{l}\text { Located in villager's rice field and } \\
\text { access roads that are usually passed } \\
\text { by the farmers }\end{array}$} \\
\hline 3 & 200 & \\
\hline 4 & 220 & \\
\hline 5 & 210 & \\
\hline 6 & 210 & \\
\hline 7 & 180 & \\
\hline 8 & 200 & \\
\hline 9 & 200 & \\
\hline 10 & 200 & \\
\hline 11 & 230 & \\
\hline 12 & 200 & \multirow{4}{*}{$\begin{array}{l}\text { Located in the community garden } \\
\text { and there are shrubs and the road } \\
\text { access and located alongside the hill }\end{array}$} \\
\hline 13 & 200 & \\
\hline 14 & 200 & \\
\hline 15 & 200 & \\
\hline
\end{tabular}




\section{CONCLUSIONS}

The development of Power Plant located on Alam Pauh Duo, Alam Pauh Duo sub-district, District of Solok Selatan is a potential area to build. This area has Geothermal in the area of South Solok, or more precisely in the Muara Laboh, most of the hot springs associated with Muara Labuh located in a Lembah Suliti River as tectonic basin along $30 \mathrm{~km}$ and a width of $2-3 \mathrm{~km}$ at an altitude of 450 meters above the sea level. The survey area has a landscape classified as Geomorphology Hills unit and Geomorphology High Hills Unit with a height of about $900-500 \mathrm{~m}$ (meters). Based on survey data that has been obtained then produced a map that has a description field site power plant and transmission tower, this area has a potential to build 15 towers as the transmission line to distribute the electricity.

\section{ACKNOWLEDGMENT}

We would like to thank PT. Surveyor Indonesia (PT. SI) Pekanbaru Branch for providing the fund of this research and also the Department of Geological Engineering, Universitas Islam Riau for permits to use tools of field mapping.

\section{REFERENCES}

[1] M. H. Dickson and M. Fanelli, Geothermal energy: utilization and technology. Routledge. 2013.

[2] E. F. Knott, Radar cross section measurements. Springer Science \& Business Media. 2012.

[3] Y. Ding, H. Liu, M. Wan and S. Xiao, "Three-Dimensional Digitalization Transfer of Ningdong-Shandong $\pm 660 \mathrm{kV}$ DC Power Transmission Pilot Project [J]," Electric Power Construction, Vol. 2(010). 2011.

[4] Y. Gao, J. Z. Yuan, Z. W. Ma and M. Z. Wan, "Development and Application of Helava Technique Based 3D Digital Simulative System for Construction Management of Transmission Lines [J]”. Power System Technology, Vol 21(016). 2007.

[5] Huang, P., Liu, R., Mo, J., \& Fang, Z. "Design of digital information share system in power distribution network," In Information Science and Control Engineering (ICISCE), 2016 3rd International Conference, pp. 938-942. IEEE. 2016.
[6] D. Sheng, X. Qie, J. Hu, Z. Wu and L. Qi, "Conducting Research and Development of Grid Information Model (GIM) Technology and Constructing the Sharing Platform of Smart Grid Technology Information," Electric Power Construction, Vol. 8(004). 2013.

[7] H. Kausarian, A. R. Shamsudin, Y. Yuskar, "Geotechnical and Rock Mass Characterization Using Seismic Refraction Method At Kajang Rock Quarry, Semenyih, Selangor Darul Ehsan," Journal of Ocean, Mechanical and Aerospace-Science and Engineering, Vol. 13. 2014

[8] H. Kausarian, J. T. S. Sumantyo, H. Kuze, J. Aminuddin, J and M. M. Waqar, "Analysis of Polarimetric Decomposition, Backscattering Coefficient, and Sample Properties for Identification and Layer Thickness Estimation of Silica Sand Distribution Using L-Band Synthetic Aperture Radar," Canadian Journal of Remote Sensing, Vol. 43(2), pp. 95-108. 2017.

[9] H. Kausarian, H., J. T. S. Sumantyo, H. Kuze, D. Karya, \& S. Wiyono, "The Origin And Distribution Of Silica Mineral On The Recent Surface Sediment Area, Northern Coastline Of Rupat Island, Indonesia," ARPN Journal of Engineering and Applied Sciences, Vol. 12(4), pp. 980-989. 2016.

[10] H. Kausarian, Batara, \& D. B. E. Putra, "The Phenomena of Flood Caused by the Seawater Tidal and its Solution for the Rapid-growth City: A case study in Dumai City, Riau Province, Indonesia," Journal of Geoscience, Engineering, Environment, and Technology, vol. 3(1), pp. 39-46. 2017

[11] M. Z. Lubis, H. M. Taki, W. Anurogo, D. S. Pamungkas, P. Wicaksono, \& T. Aprilliyanti, "Mapping the Distribution of Potential Land Drought in Batam Island Using the Integration of Remote Sensing and Geographic Information Systems (GIS)," IOP Conference Series: Earth and Environmental Science, Vol. 98(1), pp. 012012. 2017.

[12] T. D. O'Rourke and M. C. Palmer, "Earthquake performance of gas transmission pipelines," Earthquake Spectra, Vol. 3, pp. 493-527. 1996.

[13] Y. J. Li, B. Li, and S. S. Li, "Discussion on Application of the Power plant Three Dimensional Design," China Electric Power (Technology Edition), Vol. 4(012). 2012.

[14] N. Mei, D. Chen, X. Du, Y. Yang, Z. Wang and W. Cheng, "ThreeDimensional Digitalization Transfer of Qinghai-Tibet $\pm 400 \mathrm{kV}$ DC Interconnection Project [J]," Electric Power Construction, Vol. 5(008). 2012.

[15] J. Svacina, "Analysis of multilayer microstrip lines by a conformal mapping method," IEEE transactions on microwave theory and techniques, Vol. 40(4), pp. 769-772. 1992.

[16] H. A. Wheeler, "Transmission-line properties of wide parallel strips by a conformal-mapping approximation," IEEE Transactions on Microwave Theory and Techniques, Vol. 12(3), pp. 280-289. 1994. 